\title{
PEGEMBANGAN PERANGKAT PEMBELAJARAN TERPADU TIPE NETWORKED DENGAN SCIENCES, TECHNOLOGY AND SOCIETY APPROACH UNTUK MENINGKATKAN HASIL BELAJAR SISWA DI SEKOLAH DASAR
}

\author{
${ }^{1}$ Evita Gustarina, ${ }^{2}$ Budi Jatmiko, ${ }^{3}$ Suryanti \\ ${ }^{1}$ Mahasiswa Program Pascasarjana, Prodi Pendidikan Dasar, Universitas Negeri Surabaya, \\ ${ }^{2 \& 3}$ Dosen Pascasarjana, Prodi Pendidikan Dasar, Universitas Negeri Surabaya \\ e-mail: evitagustarina@gmail.com
}

Received : November 2017

Reviewed : Desember 2017

Accepted : Januari 2018

Published : Januari 2018

\section{ABSTRACT}

This research aims to produce a decent learning instrument used for integrated learning with science, technology and society approach. Eligibility can be seen from the definition, planning, validity, practicality, effectiveness, learning outcomes of the learning that has been developed. This type of research is research development. Learning instrument are developed namely RPP, LKS, BAS, ang EHB. Learning instrument using one group pretest posttest design experimental in the five grade $S D$ IT Generasi Rabbani and SD IT Al Aufa. Methods of data collection include validity, observation and tests. Data analysis using the percentage and the analysis of $N$ Gain and the analysis of anova. The results showed that 1) Validity instrument developed the content validity as seen from the study implementation plan, is student activity sheets, student's Textbook and student assessment each have average $3.54 ; 3.21 ; 3.27$ and 3.15 category either, as well as the readability of the student's Textbook and is Student Activity Sheets as developed can be categorized either. 2) The practicability of learning seen from instrument to be completed $100 \%$ done with the results assessment of to be completed class $A$ at 3.71 ; class $B$ 3.76; class $C 3.71$ excellent category. 3) Effectiveness in terms of student response devices shows the percentage of response very well to learning activities, students in grade class $A 86,85 \%$, class $B 85.68 \%$ and class $C 88.08 \%$ of the activity that the activity shows the percentage of rated very good in learning, and analysis the magnitude of the increase in the results of a study using $N$-Gain shows the Gain of the average high on all three categories class as well as an analysis with anova test showed no There is a difference of the average results of student learning in the classroom while pretest or posttest. Based on these results it can be concluded that the resulting instrument is eligible to apply to learning because it has met the three criteria, namely validity, practicality, effectiveness, results and learning activities are increasing.

Keywords: Development, integrated learning type of Networked, Sciences, Technology and Society Approach, learning activities, the results of the study.

\section{ABSTRAK}

Penelitian ini bertujuan untuk menghasilkan perangkat pembelajaran terpadu tipe networked dengan science, technology and society approach di kelas V Sekolah Dasar yang memenuhi syarat kevalidan, kepraktisan dan keefektifan sehingga dapat meningkatkan hasil belajar siswa. Jenis penelitian adalah penelitian pengembangan. Pengembangan perangkat pembelajaran terdiri atas RPP, LKS, BAS dan EHB. Perangkat pembelajaran menggunakan desain eksperimen one group pretest posttest design. Pada siswa kelas V di SD IT Generasi Rabbani dan SD IT Al Aufa. Metode Pengumpulan data meliputi validitas, observasi dan tes. Analisis data menggunakan persentase, analisis N-Gain dan analisis uji anova. Hasil penelitian menunjukkan bahwa 1) Kevalidan perangkat yang dikembangkan dilihat dari validitas isi RPP, LKS, BAS, dan EHB masing-masing memiliki rata-rata 3,54; 3,21; 
3,27 dan 3,15 berkategori baik, serta Keterbacaan BAS dan LKS yang dikembangkan dapat dikategorikan baik. 2) Kepraktisan perangkat pembelajaran dilihat dari keterlaksanaan $100 \%$ terlaksana dengan hasil penilaian keterlaksanaan RPP di kelas A 3,71; Kelas B 3,76; Kelas C 3,71 berkategori sangat baik 3) Keefektifan perangkat ditinjau dari respon siswa menunjukkan persentase respon sangat baik terhadap pembelajaran, aktivitas siswa di kelas A 86,85\%, kelas B $85,68 \%$ dan kelas C 88,08\% dari aktivitas yang dinilai menunjukkan persentase aktivitas sangat baik dalam pembelajaran, dan Analisis besarnya peningkatan hasil belajar dengan menggunakan $N$-Gain menunjukkan peningkatan rata-rata berkategori tinggi pada ketiga kelas implementasi serta Analisis dengan uji anova menunjukkan tidak terdapat perbedaan rata-rata hasil belajar siswa di kelas implementasi baik saat pretest maupun posttest. Berdasarkan hasil tersebut maka dapat disimpulkan bahwa perangkat yang dihasilkan layak untuk diterapkan pada pembelajaran karena telah memenuhi tiga kriteria yaitu kevalidan, kepraktisan, keefektifan sehingga dapat meningkatkan hasil belajar siswa.

Kata Kunci: Pengembangan Perangkat, Pembelajaran terpadu tipe Networked, Sciences, Technology and Society Approach, Hasil Belajar.

\section{PENDAHULUAN}

Proses pembelajaran pada Kurikulum 2013 untuk Pendidikan nasional berfungsi mengembangkan kemampuan dan membentuk watak serta peradaban bangsa yang bermartabat dalam rangka mencerdaskan kehidupan bangsa, bertujuan untuk berkembangnya potensi peserta didik agar menjadi manusia yang beriman dan bertaqwa kepada Tuhan Yang Maha Esa, berakhlak mulia, sehat, berilmu, cakap, kreatif, mandiri, dan menjadi warga negara yang demokratis serta bertanggung jawab (UndangUndang Nomor 20 tahun 2003).

Dalam meningkatkan mutu pendidikan melalui kegiatan pembelajaran di Sekolah Dasar adalah menjadi tanggung jawab semua pihak yang yang terlibat dalam pendidikan terutama bagi guru SD, yang memiliki peran penting dalam pendidikan awal siswa untuk ke jenjang berikutnya.

Penelitian telah menunjukkan bahwa Keterlibatan peserta didik sangat penting untuk keberhasilan belajar (Alaa Sadik:2008). Sehingga dalam proses pembelajaran Guru SD diharapkan selalu menggunakan pendekatan, strategi, dan metode pembelajaran yang dapat memudahkan siswa memahami materi yang di ajarkannya, namun pada kenyataanya di lapangan guru SD masih berkutat dengan materi pelajaran yang terlalu banyak dan keluhan kekurangan waktu untuk mengajarkan semua materi tersebut.

Oleh karena itu perubahan atau perkembangan dalam proses pembelajaran adalah hal yang memang seharusnya terjadi sejalan dengan perubahan budaya kehidupan. Perubahan dalam arti perbaikan pada semua tingkat perlu terus menerus dilakukan sebagai antisipasi kepentingan masa depan dan tuntutan masyarakat modern.
Pembelajaran terpadu adalah salah satu cara dalam mengefektifkan materi yang akan diajarkan supaya bisa menyelesaikan materi pada kurikulum dan ketuntasan materi tetap tercapai. Pembelajaran itu harus efektif dan bervariasi tentunya, hal ini sangat dibutuhkan dalam kegiatan pembelajaran sehingga proses pembelajaran tidak monoton dan setiap kegiatan pembelajaran akan menjadi bagian yang ditunggu-tunggu oleh siswa karena siswa menyukai hal-hal baru dan penuh tantangan dalam belajar.

Berdasarkan hal tersebut peneliti bermaksud untuk mengkaji salah satu hal yang berpengaruh penting dalam menunjang keefektifan suatu pembelajaran yaitu melalui model pembelajaran yang diterapkan oleh guru. Model pembelajaran harus disesuaikan dengan kebutuhan dan karakteristik siswa dan model pembelajaran terpadu menjadi model pembelajaran utama yang harus dikembangkan guru untuk mengimplementasikan Kurikulum 2013. Pembelajaran terpadu yang pertama kali dikembangkan pada awal tahun 1970-an ini diyakini para ahli pendidikan sebagai salah satu model pengajaran yang efektif (highly effective teaching model).

Menurut Sukardi (2003), pembelajaran terpadu memiliki satu tema aktual, dekat dengan dunia siswa, dan ada kaitannya dengan kehidupan sehari-hari. Tema ini menjadi alat pemersatu materi yang beragam dari beberapa materi pelajaran. Pengajaran terpadu perlu memilih materi dari beberapa mata pelajaran yang mungkin dan saling terkait. Dengan demikian materi-materi yang dipilih dapat mengungkapkan tema secara bermakna.

Kegiatan pembelajaran dimaksudkan agar tercipta kondisi yang memungkinkan terjadinya belajar pada diri siswa. Dalam suatu kegiatan pembelajaran dapat dikatakan terjadi belajar, apabila terjadi prsoes perubahan perilaku 
pada diri siswa sebagai hasil dari suatu pengalaman. Kegiatan secara langsung sebagai cara yang memungkinkan siswabelajar dengan pemahaman dan, pada saat yang sama, terlibat dalam proses pembangunan pengetahuan dengan melakukan ilmu pengetahuan. Penegasan penting ini mungkin berlaku, tetapi saat ini Penelitian juga menunjukkan bahwa membantu siswa mencapai hasil belajar yang diinginkan adalah melalui proses yang sangat kompleks. (Avi Hofstein and Vicent N. Lunetta: 2003)

Peneliti memilih mengembangkan perangkat pembelajaran terpadu tipe networked dengan pendekatan sains, teknologi, masyarakat ini karena sejalan dengan perkembangan ilmu pengetahuan sekarang ini, pada pembelajaran terpadu yang memilliki misi ahli dalam pembelajaran mengharapkan siswa lebih dalam mempelajari materi ajar, sehingga mereka (siswa) dapat menjadi ahli dari materi tersebut, dan di bidang ilmu pendidikan dikembangkan pula berbagai metode mengajar yang lebih sesuai, efektif dan efisien.

Tujuan penelitian ini adalah menghasilkan perangkat pembelajaran terpadu tipe networked dengan science, technology and society approach di kelas V Sekolah Dasar yang memenuhi syarat kevaliditasan, kepraktisan dan keefektifan sehingga dapat meningkatkan hasil belajar siswa.

Perangkat pembelajaran dikatakan efektif apabila pembelajaran dengan menggunakan perangkat tersebut dapat meningkatkaan hasil belajar secara signifikan pada taraf nyata $5 \%$ dan $\mathrm{N}$-gain berkategori minimal sedang.

\section{KAJIAN PUSTAKA}

\section{A. Pembelajaran Terpadu Tipe Networked}

Pembelajaran Terpadu merupakan model pembelajaran yang mencoba untuk memadukan beberapa pokok bahasan (Beane,1995:516) dalam prmana 2010.

Pembelajaran terpadu adalah pembelajaran yang mengintegrasikan berbagai aspek dalam pembelajaran dengan menggunakan pendekatan tematik. Untuk mencapai aspek perkembangan anak dengan optimal, materi yang disampaikan dijelaskan berdasarkan tema dan subtema.

Pembelajaran terpadu menunjukkan bahwa model pembelajaran terpadu sejalan dengan beberapa aliran modern yaitu termasuk dalam aliran pendidikan progresivisme. Aliran progresivisme memandang pendidikan yang mengutamakan penyelenggaraan pendidikan di sekolah berpusat pada anak (student centered), sebagai reaksi terhadap pelaksanaan pendidikan yang masih berpusat pada guru (teacher centered) dan pada bahan ajar. Tujuan utama sekolah adalah untuk meningkatkan kecerdasan praktis, serta untuk membuat anak lebih efektif dalam memecahkan berbagai problem yang disajikan dalam konteks pengalaman (experience) pada umumnya (Willian F. Oneill, 1981). Pembelajaran secara terpadu membuat kegiatan belajar dan mengajar melalui keaktifan siswa dalam pemahaman yang mereka bangun sendiri dengan melihat contoh nyata sehingga belajar menjadi menarik dan relevan (Edwards , Gandini , dan Forman , 2001; Murdoch dan Hornsby, 1997) .

\section{Pengertian Tipe Networked}

Tipe Networked adalah model pembelajaran terpadu berupa kerjasama antara siswa dengan seorang ahli dalam mencari data, keterangan, atau lainnya sehubungan dengan mata pelajaran yang disukainya atau yang diminatinya sehingga siswa secara tidak langsung mencari tahu dari berbagai sumber. Sumber dapat berupa buku bacaan, internet, saluran radio, TV, atau teman, kakak, orangtua atau guru yang dianggap ahli olehnya. Siswa memperluas wawasan belajarnya sendiri artinya siswa termotivasi belajar karena rasa ingin tahunya yang besar dalam dirinya. Tipe Networked merupakan rancangan kurikulum yang berfilosofi.

Menurut pandangan Robin Fogarty (1991) Networked merupakan model pemaduan pembelajaran yang mengandalkan kemungkinan pengubahan konsepsi, bentuk pemecahan masalah, maupun tuntutan bentuk keterampilan baru setelah siswa mengadakan studi lapangan dalam situasi, kondisi, maupun konteks yang berbeda-beda. Belajar disikapi sebagai proses yang berlangsung secara terus-menerus karena adanya hubungan timbal balik antara pemahaman dan kenyataan yang dihadapi siswa.

\section{B. Pendekatan Sains,Teknologi, dan Masyarakat (STM)}

Pendekatan STM (Sains Teknologi Masyarakat) adalah suatu usaha untuk menyajikan sains (IPA) melalui pemanfaatan masalah-masalah dalam kehidupan seharihari. Pendekatan sains teknologi dan masyarakat melibatkan siswa dalam penentuan tujuan pembelajaran, prosedur pelaksanaan pembelajaran, pencarian informasi bahan pembelajaran dan bahkan pada evaluasi belajar. Tujuan utama pendekatan sains teknologi dan masyarakat (STM) yaitu agar dihasilkan siswa-siswa yang memiliki bekal ilmu dan pengetahuan agar nantinya mampu mengambil keputusan-keputusan terkait masalah-masalah dalam masyarakat. Pendekatan sains teknologi dan masyarakat (STM) berlandaskan 3 hal yaitu:

Hubungan erat antara sains, teknologi dan masyarakat. 
Proses belajar-mengajar didasarkan kepada teori konstruktivisme, dimana siswa membangun sendiri pengetahuannya saat berinteraksi dengan lingkungan.

Ada 5 ranah pembelajaran, yaitu (1) ranah kognitif, (2) ranah afektif, (3) ranah proses sains, (4) ranah kreativitas, dan (5) ranah hubungan dan aplikasi.

Langkah-langkah pembelajaran pendekatan STM ini perlu diperhatikan. Menurut Robert E. Yager (1992) sintaks model pembelajaran STM adalah sebagai berikut: LangkahLangkah / Sintaks :

\section{Fase 1 (Invitasi)}

Pada fase pertama ini (invitasi) guru mengundang siswa untuk aktif dalam pembelajaran. Guru mulai menggali isu atau masalah dari siswa. Untuk melakukan ini guru dapat mengajukan pertanyaan-pertanyaan yang mendorong siswa untuk memunculkan permasalahan.

\section{Fase 2 (Eksplorasi)}

Pada fase kedua (eksplorasi), siswa di bawah arahan dan fasilitasi guru membentuk kelompok-kelompok yang selanjutnya setiap kelompok akan mencoba merancang dan melakukan kegiatan eksperimen atau percobaan untuk mengumpulkan data. Pada tahapan ini mereka akan berlatih menggunakan keterampilan proses sains.

\section{Fase 3 (Pengajuan Eksplanasi dan solusi)}

Pada fase ketiga (pengajuan eksplanasi dan solusi) siswa akan berusaha membangun sendiri pengetahuannya (sesuai dengan teori konstruktivisme). Mereka akan berdiskusi dan mencoba menjelaskan apa yang sedang terjadi, atau mengapa sesuatu bisa terjadi, selanjutnya mereka akan mencoba menemukan solusi atau pemecahan masalah. Dalam hal ini, tentu saja solusi atau pemecahan masalah yang diberikan sesuai dengan informasi-informasi yang mereka peroleh dari kegiatan eksplorasi (fase 2).

\section{Fase 4 (Tindak Lanjut)}

Pada fase keempat (tindak lanjut) yang merupakan fase terakhir dari penerapan pendekatan STM (sains teknologi dan masyarakat) ini, guru membantu siswa untuk menjelaskan fenomena alam berdasarkan konsep-konsep yang baru saja mereka bangun. Selain itu juga membantu siswa menjelaskan berbagai aplikasi untuk memberikan makna terhadap informasi yang baru saja mereka peroleh, dan melakukan refleksi terhadap pemahaman konsep.

\section{Aktivitas Belajar}

Belajar menurut Oemar Hamalik (2003:28), adalah "Suatu proses perubahan tingkah laku individu melalui interaksi dengan lingkungan".Aspek tingkah laku tersebut adalah: pengetahuan, pengertian, kebiasaan, keterampilan, apresiasi, emosional, hubungan sosial, jasmani, etis atau budi pekerti dan sikap. Jika seseorang telah belajar maka akan terlihat terjadinya perubahan pada salah satu atau beberapa aspek tingkah laku tersebut. Selanjutnya Sardiman A.M. (2012:22) menyatakan: "Belajar sebagai suatu proses interaksi antara diri manusia dengan lingkungannya yang mungkin berwujud pribadi, fakta, konsep ataupun teori”.

Dalam proses interaksi ini terkandung dua maksud yaitu: 1.Proses Internalisasi dari sesuatu ke dalam diri yang belajar. 2. Proses ini dilakukan secara aktif dengan segenap panca indera ikut berperan

Dari uraian tentang belajar di atas peneliti berpendapat bahwa dalam belajar terjadi dua proses yaitu 1. perubahan tingkah laku pada diri seseorang yang sedang belajar, 2. Interaksi dengan lingkungannya, baik berupa pribadi, fakta, dsb.Jadi peneliti berkesimpulan bahwa aktivitas belajar adalah segala kegiatan yang dilakukan dalam proses interaksi (guru dan siswa) dalam rangka mencapai tujuan belajar.

Aktivitas yang dimaksudkan di sini penekanannya adalah pada siswa, sebab dengan adanya aktivitas siswa dalam proses pembelajaran terciptalah situasi belajar aktif, seperti yang dikemukakan oleh Rochman Natawijaya (dalam Depdiknas, 2006: 31), belajar aktif adalah "Suatu sistem belajar mengajar yang menekankan keaktifan siswa secara fisik, mental intelektual dan emosional guna memperoleh hasil belajar yang berupa perpaduan antara aspek kognitif, afektif dan psikomotor".

Aktivitas belajar itu banyak sekali macamnya, sehingga para ahli mengadakan klasifikasi. Paul D. Dierich, dalam Oemar Hamalik (2003:172) mengklasifikasikan aktivitas belajar atas delapan kelompok, yaitu:

a. Kegiatan-kegiatan Visual Membaca, melihat gambar-gambar, mengamati eksperimen, demonstrasi, pameran, dan mengamati orang lain bekerja dan bermain.

b. Kegiatan-kegiatan Lisan (oral) Mengemukakan suatu fakta atau prinsip, menghubungkan suatu kejadian, mengajukan pertanyaan, memberi saran, mengemukakan pendapat, wawancara, diskusi dan interupsi.

c. Kegiatan-kegiatan Mendengarkan Mendengarkan penyajian bahan, mendengarkan percakapan atau diskusi kelompok, mendengarkan suatu permainan, mendengarkan radio.

d. Kegiatan-kegiatan Menulis cerita, menulis laporan, memeriksa karangan, bahan-bahan kopi, 
membuat rangkuman, mengerjakan tes dan mengisi angket.

e. Kegiatan-kegiatan Menggambar Menggambar, membuat grafik, chart, diagram, peta dan pola.

f. Kegiatan-kegiatan Metrik Melakukan percobaan, memilih alat-alat, melaksanakan pameran, membuat model, menyelenggarakan permainan, menari dan berkebun.

g. Kegiatan-kegiatan Mental Merenung, mengingat, memecahkan masalah, menganalisis faktorfaktor, melihat hubungan-hubungan dan membuat keputusan.

h. Kegiatan-kegiatan Emosional Minat, membedakan, berani, tenang dan lain-lain.

Berdasarkan pengertian aktivitas tersebut di atas, peneliti berpendapat bahwa dalam belajar sangat dituntut keaktifan siswa.Siswa yang lebih banyak melakukan kegiatan sedangkan guru lebih banyak membimbing dan mengarahkan.Tujuan pembelajaran tidak mungkin tercapai tanpa adanya aktifitas siswa, peneliti berusaha melatih dengan penerapan pembelajaran terpadu tipe networked dengan pendekatan sains teknologi masyarakat, sebab dalam model pembelajaran ini siswa dituntut untuk aktif dan bertanggung jawab baik secara individu maupun kelompok.

Dari uraian di atas peneliti berpendapat bahwa dengan adanya motivasi siswa dalam belajar, maka aktivitas siswa dalam proses pembelajaran juga akan meningkat. Aktivitas Siswa yang Diamati Dalam penelitian ini peneliti akan mengamati aktivitas siswa sebagai berikut:

1) Mengajukan pertanyaan

2) Menjawab pertanyaan

3) Memberi saran

4) Mengemukakan pendapat

5) Menyelesaikan tugas kelompok

6) Mempresentasikan hasil kerja kelompok

\section{Hasil Belajar}

Dalam proses pembelajaran agar hasil belajar siswa meningkat harus terjadi interaksi antara guru dan siswa agar terjadinya suatu perubahan tingkah laku dalam individu (siswa), dan guru harus melakukan berbagai usaha untuk mencapai tujuan belajar. Pengertian hasil belajar seperti yang dikemukakan oleh Sudjana (2006:76) mengatakan bahwa "hasil belajar pada hakikatnya adalah perubahan tingkah laku sebagai hasil belajar dalam pengertian yang luas mencakup bidang kognitif, afektif dan psikomotorik"

Sehubungan dengan hal itu Menurut Bennyamin Blom dalam Sudjana hasil belajar dapat dikelompokan menjadi tiga ranah yaitu ranah kognitif, psikomotor, dan afektif (Sudjana, 2010:22).

Pengembangan pembelajaran merupakan hal yang penting sedapatnya harus dipenuhi oleh guru sebelum melaksanakan proses pembelajaran. Pembelajaran yang telah direncanakan dan dikembangkan secara optimal akan memberikan pengaruh pada kegiatan dan keaktifan peserta didik dalam belajar. Jika pengembangan pembelajaran telah dituangkan dalam perangkat pembelajaran yang disiapkan secara matang maka proses PAIKEM yaitu pembelajaran yang aktif, inovatif, kreatif, efektif dan menyenangkan akan terlaksana di dalam kegiatan pembelajaran sehari-hari di sekolah, terutama Sekolah Dasar (SD).

"Good plans give you the security of knowing what you will do and say, of having interesting activities and materials ready for the children's use, and of anticipating what the children might do" (Reys, 2009:47). Perencanaan yang baik akan membuat pembelajaran terkonsep sehingga pembelajaran akan menarik bagi siswa, dan guru akan mendapat gambaran apa yang akan dilakukan siswa dalam pembelajaran. Salah satu bentuk perencanaan pembelajaran adalah perangkat pembelajaran. Reys menjelaskan bahwa perangkat pembelajaran meliputi perencanaan tahunan, perencanaan tiap unit dan perencanaan harian. Dalam penelitian ini perangkat pembelajaran yang dimaksud adalah sekumpulan sumber belajar yang menunjang guru dan siswa melakukan kegiatan pembelajaran dengan baik. Membuat tujuan pembelajaran eksplisit akan membantu Anda merancang program Anda dan akan membantu siswa fokus pada kegiatan belajar mereka. "Idenya adalahsederhana: kita harus memiliki gagasan yang jelas tentang apa hasil yang diharapkan tentu saja adalah jika salah satu adalah untuk keinginana mengembangkannya "(Menges, Weimer, \& Associates, 1996, hal. 188).

E. Teori belajar yang melandasi pembelajaran terpadu tipe networked dengan pendekatan sains teknologi masyarakat (STM)

\section{Teori Belajar Gestalt}

Teori ilmu jiwa Gestalt berpandangan bahwa keseluruhan lebih penting dari bagian-bagian/unsur.

Menurut aliran teori belajar ini, seseorang belajar jika mendapatkan insight. Insight ini diperoleh kalau seseorang melihat hubungan tertentu antara berbagai unsurakan situasi tertentu.

\section{Teori Piaget}

Jean Piaget adalah ahli psikologi yang berasal dari Switzerland. Ide Piaget tentang sifat-sifat perkembangan kognitif adalah 
a. Anak adalah pebelajar yang aktif. Piaget meyakini bahwa anak secara natural memiliki rasa ingin tahu dan secara aktif berusaha mencari informasi untuk membantu pemahamannya tentang realitas dunia yang mereka hadapi. Dalam memahami dunia mereka secara aktif anak menggunakan apa yang disebut oleh piaget dengan skema, yaitu integrated network of knowledge which are atored in long term memory and allow us to recall, undesrand and create expectations (Pritchard, 2010:10). Artinya skema adalah jaringan pengetahuan yang tersimpan dalam memori jangka panjang dan memungkinkan kita untuk menggali, memahami dan membuat dugaan.

b. Anak mengorganiasai apa yang mereka pelajari dari pengalamannya. Anak-anak mengumpulkan faktafakta yang terpisah, kemudian memanipulasinya menjadi satu kesatuan.

c. Anak menyesuaikan diri dengan lingkungan melalui proses asimilasi dan akomodasi. Proses adaptasi skema dengan pengetahuan baru terjadi melalui dua kemungkinan, yaitu (1) asimilasi, jika anak memasukkan pengetahuan baru secara langsung, dengan kata lain pengetahuan baru tersebut sudah relevan dengan skema yang ada dan (2) akomodasi, jika anak menyesuaikan diri pada informasi baru dengan mengubah skema terlebih dahulu agar pengetahuan tersebut menjadi relevan

d. Proses ekuilibrasi menunjukkan adanya peningkatan ke arah bentuk-bentuk pemikiran yang lebih kompleks. Saat seseorang berhadapan dengan situasi yang tidak dipahaminya, maka akan timbul konflik kognitif yang disebut dengan disequilibrium, yaitu semacam ketidaknyamanan mental yang mendorong seseorang mencoba membuat pemahaman tentang apa yang mereka temui. Melalui asimilasi atau akomodasi, anak-anak akhirnya akan mampu memecahkan konflik dan mencapai keadaan equilibrium, yaitu keadaan seimbang antara struktur kognitifnya dan pengalaman barunya di lingkungan. Pergerakan dari equilibrium ke disequilibrium dan kemudian kembali ke equilibrium merupakan proses meningkatkan perkembangan pemikiran dan pengetahuan ke tahap yang lebih kompleks, yang disebut piaget dengan istilah equilibration (equilibrasi).

\section{Teori Vygotsky}

Menurut Vygotsky sebagaimana dikutip Nur mengemukakan teori bahwa perkembangan kognitif sangat erat terkaitnya dengan masukan dari orang lain (Nur, 2004:45). Elemen penting perkembangan kognitif menurut Vygotsky dalam Pritchard adalah interaksi sosial, ZPD (Zona of Proximal Development), dan Scaffolding (Pritchard, 2010:14).

\section{F. Penelitian Yang Relevan}

Penelitian yang relevan dengan penelitian ini adalah penelitian yang dilakukan oleh Sanimah (2014) Penerapan pembelajaran ipa terpadu model integrated dan networked menggunakan socioscientific issues untuk meningkatkan kemampuan pemecahan Masalah dan kepedulian lingkungan siswa Smp pada tema pencemaran air, Subjek penelitian adalah siswa kelas VII SMP Negeri di Kota Stabat Provinsi Sumatera Utara. Hasil penelitian menunjukkan bahwa pembelajaran IPA terpadu menggunakan Socioscientific Issues sudah sesuai dengan yang direncanakan. Peningkatan kemampuan pemecahan masalah dan peningkatan kepedulian lingkungan berbeda secara signifikan antara kelas yang memperoleh pembelajaran IPA terpadu model integrated dengan pembelajaran IPA terpadu model networked menggunakan Socioscientific Issues.

Penelitian menggunakan pendekatan STM ini dilakukan juga oleh Wafa fauziah (2013), Penelitian ini dilatarbelakangi hasil belajar siswa di kelas IV pada mata pelajaran IPA rata-rata masih di bawah KKM yaitu 40,6\% dengan KKM yaitu 60. Metode yang digunakan guru masih menggunakan metode konvensional yaitu metode ceramah. Kesimpulan penelitian ini adalah penerapan pendekatan STM dalam pembelajaran IPA materi Bumi dan Alam Semesta dapat meningkatkan hasil belajar siswa. Saran dari hasil penelitian ini yaitu Penerapan pendekatan STM dapat menjadi alternatif dalam pembelajaran di kelas.

Selain itu penelitian yang dilakukan oleh lailatul nuraini (2014) tujuan penelitian ini mendapatkan tampilan perbaikan literasi sains siswa proses sains aspec di SMK melalui model Sains Teknologi Masyarakat dengan penerapan metode ilmiah. Hasil penelitian ini menunjukkan bahwa literasi sains Model Sains Teknologi Masyarakat digunakan tanpa metode ilmiah peningkatan siswa Model Sains Teknologi Masyarakat dengan metode ilmiah yang lebih tinggi daripada siswa literasi sains digunakan '. NGain kelas eksperimen adalah 0,31 dan kontrol adalah 0,24 dengan $\alpha=0,05$. Respon siswa adalah setuju dan respon guru yang kuat setuju bahwa penerapan model Sains Teknologi Masyarakat dengan metode ilmiah dapat digunakan untuk meningkatkan minat dan motivasi siswa, memiliki keuntungan dari ilmu pengetahuan dan teknologi dalam kehidupan sehari-hari dan literasi sains siswa. 


\section{G. Kerangka Berpikir}

Pembelajaran Terpadu merupakan model pembelajaran yang mencoba untuk memadukan beberapa pokok bahasan (Beane,1995: 615) dalam Permana 2010. Model pembelajaran terpadu merupakan salah satu model implementasi kurikulum yang dianjurkan untuk diaplikasikan pada semua jenjang pendidikan, mulai dari tingkat taman kanak-kanak sampai SMA. Model pembelajaran ini pada hakikatnya merupakan suatu pendekatan pembelajaran yang memungkinkan peserta didik baik secaraa individual maupun kelompok aktif untuk mencari, menggali, dan menemukan konsep serta prinsip secara holistic dan otentik.

Pembelajaran terpadu diawali dari suatu pokok bahasan atau tema tertentu yang dikaitkan dengan pokok bahasan lainnya, dimana konsep tertentu dikaitkan dengan konsep lain yang telah direncanakan, baik dalam satu bidang atau lebih dan dengan beragam pengalaman belajar agar pembelajaran menjadi lebih bermakna (Hardisubroto,1998) dalam permana 2010. Pembelajaran terpadu Tipe Networked adalah model pembelajaran terpadu berupa kerjasama antara siswa dengan seorang ahli dalam mencari data, keterangan, atau lainnya sehubungan dengan mata pelajaran yang disukainya atau yang diminatinya sehingga siswa secara tidak langsung mencari tahu dari berbagai sumber.

Menurut pandangan Fogarty (1991) networked merupakan model pemaduan pembelajaran yang mengandalkan kemungkinan pengubahan konsepsi, bentuk pemecahan masalah, maupun tuntutan bentuk keterampilan baru setelah siswa mengadakan studi lapangan dalam situasi, kondisi, maupun konteks yang berbeda-beda.

Jika pembelajaran terpadu tipe networked ini dilaksanakan dalam pembelajaran diharapkan dapat memberikan bekal kepada siswa untuk mampu memfilter (memilih) seluruh kegiatan belajar melalui kacamata keahlian dan kemampuan membuat hubungan internal dan mampu memandu ke jaringan kerja eksternal dari para ahli di lapangan atau bidang-bidang terkait. Sebagai contoh yaitu seorang arsitek ketika mengadaptasi sebuah program ia bekerja sama dengan ahli teknik pemrograman, dan ahli interior desain. Ia bekerja secara lintas bidang dan bekerjasama dengan keahlian pelajar lain untuk memperoleh keterampilan yang sempurna.

Melalui penggunaan pendekatan Sains Teknologi Masyarakat (STM) yang merupakan salah satu pendekatan pembelajaran kontekstual yang mana pendekatan ini dapat membantu siswa untuk membuat pembelajaran menjadi lebih berarti. Karena di dalam Sains Teknologi Masyarakat (STM) ini berkaitan dengan kehidupan yang nyata, pembelajaran yang bersumber dari pendekatan Sains Teknologi Masyarakat (STM) disini siswa memiliki perasaan, perhatian, kemauan, ingatan dan pikiran yang mengalami perubahan berkat pengalaman hidup.

Dari pembahasan di atas, dapat disimpulkan bahwa pendidikan harus dapat mempergunakan sumber-sumber pengetahuan yang ada di masyarakat karena dengan melihat apa yang terjadi di masyarakat anak didik akan mendapatkan pengalaman langsung (first hand experience) dan oleh karenanya mereka dapat memiliki pengalaman yang konkret (jelas dan nyata) serta mudah diingat. Pendidikan membina anak-anak yang berasal dari masyarakat, dan akan kembali ke masyarakat, di masyarakat banyak sumber pengetahuan yang mungkin guru sendiri belum mengetahuinya.

Oleh karena itu agar pembelajaran terpadu tipe networked dengan pendekatan sanis teknologi masyarakat dapat berlangsung secara sistematis maka perlu dikembangkan perangkat pembelajarannya. Dengan perangkat pembelajaran yang memenuhi syarat kevalidan, kepraktisan dan keefektifan diharapkan hasil belajar siswa akan meningkat.

\section{METODE}

Penelitian ini merupakan penelitian pengembangan yaitu mengembangkan perangkat pembelajaran terpadu tipe networked dengan pendekatan sains teknologi dan masyarakat (science, technology and society approach). Uji coba perangkat pembelajaran ini dilaksanakan di kelas V Sekolah Dasar Islam Terpadu (SD IT) Generasi Rabbani dan Al Aufa Kota Bengkulu.

Adapun waktu pelaksanaan uji coba adalah pada semester 2 tahun pelajaran 2015/2016. Subjek Penelitian ini adalah perangkat pembelajaran terpadu tipe networked yang terdiri atas RPP, LKS, BAS, dan EHB. Perangkat pembelajaran diujicobakan di Sekolah Dasar (SD). Prosedur dalam penelitian ini terdiri atas dua tahap yaitu tahap pengembangan perangkat pembelajaran terpadu tipe networked dengan pendekatan sains teknologi masyarakat (STM) dan tahap implementasi perangkat pembelajaran di kelas $\mathrm{V}$.

Model pengembangan perangkat yang digunakan dalam penelitian ini adalah four-DModels (model $4 \mathrm{D}$ ) yang telah direduksi. Reduksi yang dilakukan antara lain penyederhanaan tahap-tahap pengembangan yaitu tahap pendefinisian (define), tahap perancangan (design) dan tahap pengembangan (develop), sedangkan tahap penyebaran (desiminate) tidak dilaksanakan.

Dalam penelitian ini dikembangkan instrument berupa 5 jenis instrumen, yaitu: (1) lembar validasi perangkat, (2) 
lembar penilaian keterbacaan BAS dan LKS (3) lembar pengamatan keterlaksanaan perangkat, (4) lembar pengamatan aktifitas siswa, (5) lembar angket respon siswa dan (5) tes hasil belajar. Metode Pengumpulan data

1. Pengamatan (Observasi)

2. Pemberian Tes

3. Penyebaran Angket

Untuk menganalisis data yang diperoleh selama penelitian, peneliti menggunakan analisis deskriptif kuantitatif.

1. Analisis Kualitas Perangkat Pembelajaran

Analisis Validitas Perangkat

Analisis Keterbacaan BAS dan LKS

2. Kepraktisan Perangkat Pembelajaran

Analisis keterlaksanaan pembelajaran

Analisis Kendala Pelaksanaan pembelajaran

3. Keefektifan Perangkat Pembelajaran

Analisis keefektifan perangkat pembelajaran meliputi respon siswa, aktivitas siswa dan hasil belajar siswa.

a. Analisis tes hasil belajar

1) Analisis t-tes berpasangan

Untuk mengetahui signifikansi peningkatan hasil belajar antara pretest dan posttest diakukan uji hipotesis dengan menggunakan uji $\mathrm{t}$ berpasangan.

2) N Gain

Analisis N Gain dilakukan untuk mengetahui besarnya peningkatan hasil belajar menggunakan uji perbedaan rata-rata pretest dan postest. Besarnya peningkatan atau gain dianalisis dengan rumus Hake.

$(g)=\frac{\left(s_{\text {post }}\right)-\left(s_{\text {pre }}\right)}{100 \%-\left(s_{\text {pre }}\right)}$

(Hake, 1999)

3) Analisis Varians

Analisis varians bertujuan untuk menguji tidak adanya perbedaan mean tiga kelompok sekaligus. Analis varians yang dilakukan dalam penelitian ini meliputi analisis varian pretes dan analisis varians post tes.

\section{HASIL DAN PEMBAHASAN}

\section{A. Kevalidan}

Perangkat pembelajaran yang dikembangkan dapat dilihat dari Validitas isi rencana pelaksanaan pembelajaran, lembar kegiatan siswa, buku ajar siswa, dan evaluasi hasil belajar yang dikembangkan masing-masing memiliki ratarata 3,$54 ; 3,21 ; 3,27$ dan 3,15 dapat dikategorikan baik sehingga dapat digunakan dengan revisi kecil.

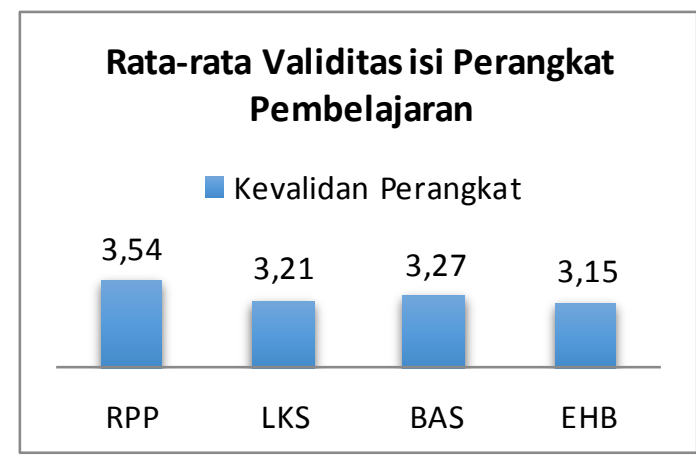

Diagram 1

BAS dan LKS merupakan lembar perangkat sebagai bagi siswa untuk dipelajari agar dapat memahami materi. Keterbacaan BAS dan LKS diperoleh dari angket keterbacaan yang diberikan kepada siswa.

Penilaian keterbacaan BAS dan LKS pada Gambar 2 dan Gambar 3.

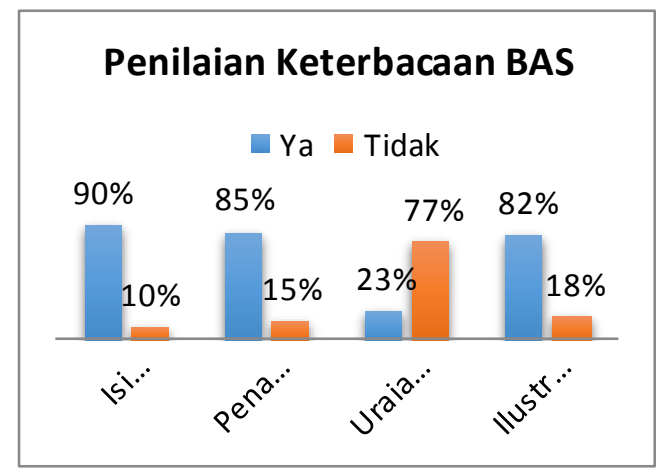

Diagram 2

Sesuai dengan gambar 2 diperoleh $90 \%$ siswa menjawab isi BAS menarik, $85 \%$ siswa menjawab penampilan buku menarik, $77 \%$ siswa menjawab uraian buku tidak terlalu sulit dan $82 \%$ siswa menjawab ilustrasi gambar mudah dipahami.

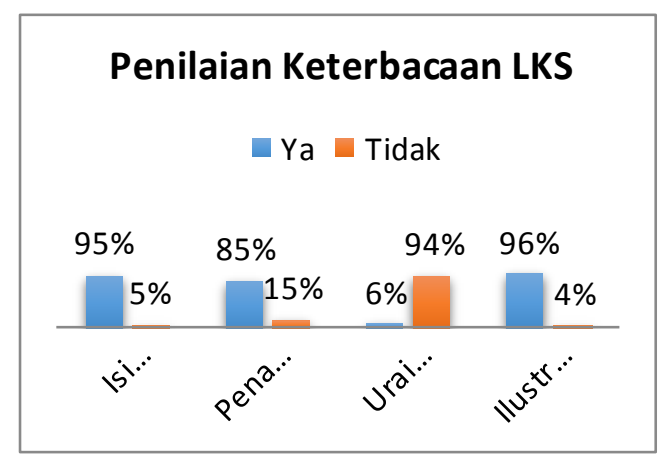

Diagram 3 
Sesuai dengan gambar 3 diperoleh $95 \%$ siswa menjawab isi LKS menarik, $85 \%$ siswa menjawab penampilan LKS menarik, $94 \%$ siswa menjawab uraian LKS tidak terlalu sulit dan $96 \%$ siswa menjawab ilustrasi gambar mudah dipahami.

\section{B. Kepraktisan}

Perangkat pembelajaran yang dikembangkan dan diimplementasikan dilihat dari keterlaksanaan kegiatan pembelajaran terpadu tipe networked dengan science, technology and society aaproach $100 \%$ terlaksana dengan hasil penilaian keterlaksanaan RPP di kelas A 3,71; Kelas B 3,76; Kelas C 3,71 dapat dikategorikan sangat baik, seperti yang terlihat pada Gambar 4.

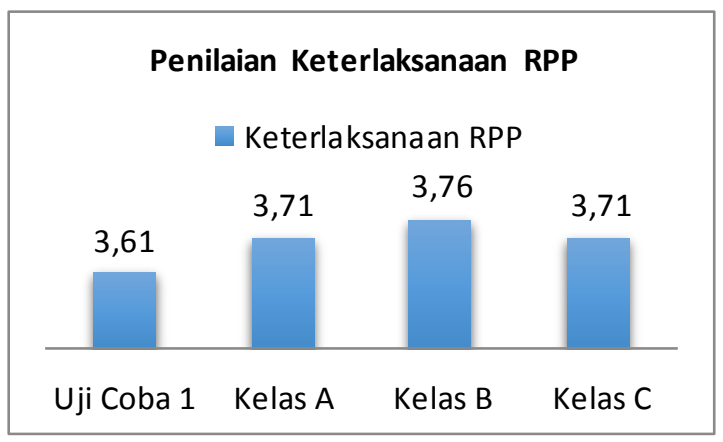

\section{Diagram 4}

Kendala-kendala yang ditemui selama kegiatan pembelajaran terpadu tipe networked dengan science, technology and society aaproach bertemakan lingkungan adalah siswa belum terbiasa menggunakan kegiatan pembelajaran terpadu ini sehingga siswa masih bingung pada pelaksanaan pembelajaran.

\section{Keefektifan}

Perangkat pembelajaran yang dikembangkan dan diimplementasikan pada respon siswa kelas setelah pembelajaran menunjukkan rata-rata Kelas A 91,85\% Kelas B 88,83\% dan Kelas C 87,55\%. Hal ini menunjukkan respon semua kelas implementasi berkategori sangat baik. Persentase respon siswa mengidentifikasikan bahwa penggunaan metode pembelajaran terpadu membuat siswa tertarik untuk belajar, komponen yang digunakan dalam pembelajaran terpadu tipe networked dengan pendekatan sains, teknologi dan masyarakat (STM) /science, technology, and society approach merupakan hal yang baru bagi siswa, dan penggunaan metode pembelajaran terpadu tipe networked dengan pendekatan sains, teknologi dan masyarakat (STM) /science, technology, and society approach menarik bagi siswa.
Berdasarkan kriteria Trianto (2010) Kriteria penilaian menggunakan persentase $81 \%$ - 100\% dikategorikan sangat baik maka dapat disimpulkan bahwa perangkat sangat efektif digunakan untuk pembelajaran.

Aktivitas belajar siswa yang menggunakan perangkat pembelajaran terpadu tipe networked dengan science, technology and society aaproach di kelas A 86,85\%, kelas B $85,68 \%$ dan kelas C 88,08\% dari aktivitas yang dinilai dilaksanakan sehingga dapat dikategorikan sangat baik pada Gambar 6.

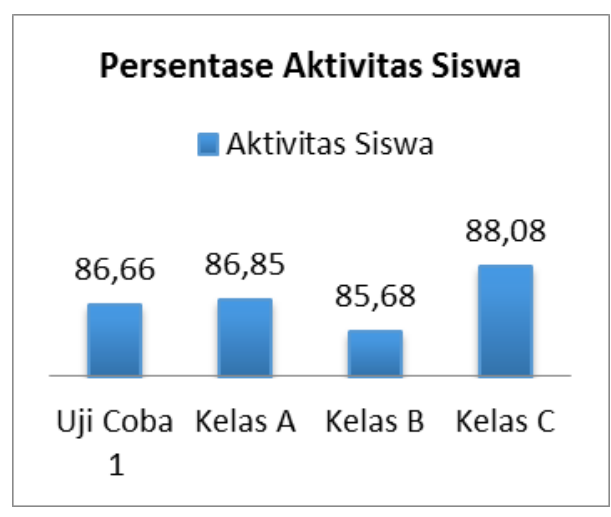

Diagram 5

Keaktifan siswa yang terjadi selama pelaksanaan pembelajaran membuktikan bahwa pembelajaraan dengan kerjasama kelompok memberi peluang terjadinya proses partisipasi aktif peserta didik dalam belajar dan terjadinya dialog interaktif Suprijono (2005:66). Peran guru sebagai fasilitator dalam pembelajaran membuktikan bahwa pembelajaran dengan kerjasama kelompok mengubah peran guru dari center stage performance menjadi koreografer kegiatan kelompok Suprijono (2005:66).

Melalui kegiatan aktif, karena siswa harus berpikir secara mendalam dan mempertimbangkan masalah dari berbagai aspek selama proses pembelajaran. Namun ketika melakukan tugas-tugas pembelajaran, itu adalah tantangan bagi guru untuk melibatkan siswa dalam diskusi kelompok dan interaksi, khususnya disebagian besar sekolah di Asia di mana mentransfer pengetahuan kepada siswa untuk ujian dianggap sebagai tujuan utama pengajaran. (Sung,H.Y.,Hwang, G. J., \& Chang, H. S:2015).

Analisis peningkatan hasil belajar siswa yang menggunakan perangkat pembelajaran terpadu tipe networked dengan science, technology and society aaproach sebelum dan sesudah pembelajaran. Hasil belajar kognitif siswa diukur dengan pre test dan post test. Pre test diberikan di awal pembelajaran untuk mengetahui kemampuan awal siswa. Setelah diberikan perlakuan, siswa diberikan tes akhir (post-test). 


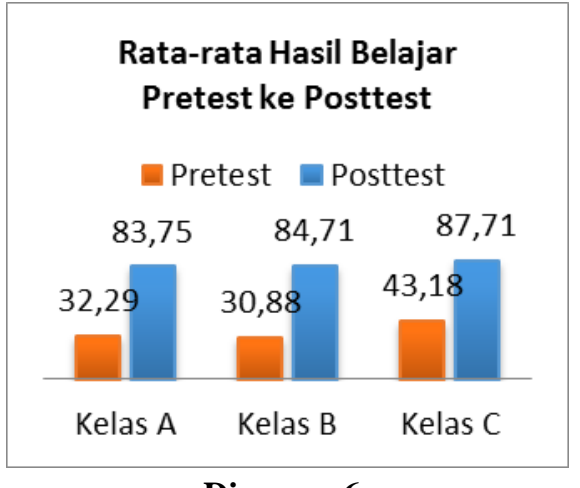

Diagram 6

Berdasarkan Gambar 7 diketahui bahwa rata-rata pretest kognitif siswa Kelas A 32,29, Kelas B 30,88, dan Kelas C 43,18 , dan terjadi peningkatan rata-rata kognitif hasil belajar pada posttest siswa Kelas A 83,75, Kelas B 84,71 dan Kelas C 87,71.

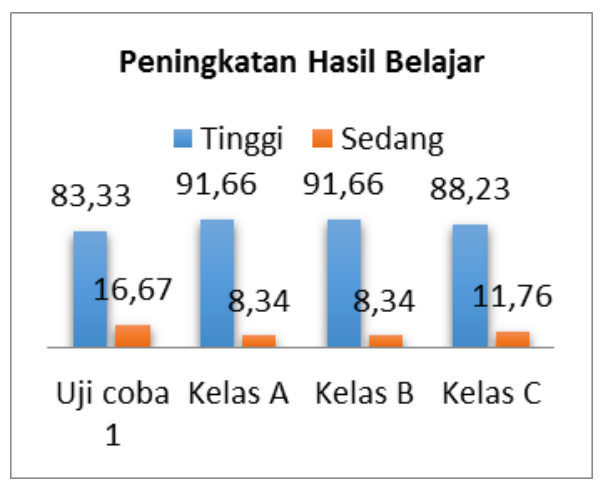

Diagram 7

Pada gambar 8 diketahui bahwa ketiga kelas menunjukkan peningkatan hasil belajar secara signifikan sebelum dan sesudah pelaksanaan pembelajaran terpadu tipe neworked dengan pendekatan sains, teknologi, dan masyarakat. Hal ini berdasarkan hasil analisis menggunakan uji t di kelas A,kelas B dan kelas C yaitu diketahui bahwa hasil post test lebih besar dari pada hasil pre test. Peningkatan hasil belajar ini juga dianalisis dengan N Gain. Hasil N-Gain pada kelas A dengan rata-rata 0,77 dikategorikan peningkatan tinggi, hasil N-Gain pada kelas B dengan ratarata 0,78 dikategorikan peningkatan tinggi,dan hasil $\mathrm{N}$ Gain pada kelas $\mathrm{C}$ dengan rata-rata 0,85 dikategorikan peningkatan tinggi. Sehingga hasil uji t dan $\mathrm{N}$-gain dari hasil belajar siswa secara signifikan pada taraf nyata $5 \%$ dapat meningkatkan hasil belajar siswa melalui penerapan pembelajaran terpadu tipe networked dengan pendekatan sains,teknologi dan masyarakat.

Sementara itu, perbedaan rata-rata hasil belajar siswa tersebut dianalisis dengan analisis varians satu jalur. Diketahui bahwa tidak terdapat perbedaan rata-rata hasil belajar siswa baik saat pretest maupun posttest. Hal ini menunjukkan konsistensi hasil belajar dengan menggunakan perangkat pembelajaran terpadu tipe neworked dengan pendekatan sains, teknologi dan masyarakat ini.

Peningkatan hasil belajar tidak terlepas dari ketersediaan perangkat pembelajaran yang valid, terlaksananya rencana pelaksanaan pembelajaran dengan baik, siswa yang aktif selama proses belajar. Melalui proses pembelajaran agar hasil belajar siswa meningkat harus terjadi interaksi antara guru dan siswa agar terjadinya suatu perubahan tingkah laku dalam individu (siswa), dan guru harus melakukan berbagai usaha untuk mencapai tujuan belajar. Pengertian hasil belajar seperti yang dikemukakan oleh Sudjana (2006:76) mengatakan bahwa "hasil belajar pada hakikatnya adalah perubahan tingkah laku sebagai hasil belajar dalam pengertian yang luas mencakup bidang kognitif, afektif dan psikomotorik".

Peningkatan hasil belajar dalam Pembelajaran adalah ketika peserta didik memperoleh pengetahuan dan keterampilan dengan melakukan kegiatan nyata, situasi interaktif; ini memungkinkan mereka untuk secara rasional dan bermakna menafsirkan pengetahuan dan keterampilan yang diperoleh selama proses tersebut (Brown, Collins, dan Duguid, 1989; McLellan, 1996). Pengetahuan baru yang diperoleh oleh peserta didik melalui pembelajaran terletak tidak terisolasi atau terpecah-pecah tapi lengkap dan pengetahuan yang komprehensif yang benar-benar menguasai berikut reorganisasi (Huang, C. S. J., Yang, S. J. H., Chiang, T. H. C., \& Su, A. Y. S:2016).

\section{SIMPULAN DAN SARAN}

Berdasarkan analisis, definisi operasional, pembahasan hasil, dan temuan penelitian serta definisi operasional maka dapat disimpulkan pengembangan perangkat model pembelajaran terpadu tipe networked dengan science, technology and society approach (STS) untuk meningkatkan hasil belajar siswa Kelas V Sekolah Dasar telah memenuhi syarat kevalidan, kepraktisan dan keefektifan sehingga layak digunakan dalam proses pembelajaran.

Berdasarkan hasil penelitian yang telah dilakukan maka terdapat beberapa saran yaitu

1. Kegiatan pembelajaran akan lebih menyenangkan dan bermakna jika proses pembelajaran di kelola secara baik dan efektif sehingga tujuan pembelajaran dapat tercapai sesuai dengan yang telah ditentukan.

2. Penelitian selanjutnya perlu dilakukan perbaikan sehingga pengembangan perangkat pembelajaran 
terpadu yang dihasilkan jauh lebih baik, dan apabila peneliti lain ingin melakukan penelitian yang sejenis, mungkin hasil penelitian ini dapat digunakan sebagai referensi dalam melakukan penelitian yang lebih komprehensif dengan setting kegiatan yang berbeda serta peneliti lain juga dapat melakukan peninjauan lain terhadap pengaruh penerapan model pembelajaran terpadu tipe networked dengan science, technology and society approach (STS) selain aktivitas dan hasil belajar kognitif siswa, misalkan hasil belajar psikomotor, afektif, motivasi belajar, kreativitas siswa, keterampilan berpikir dan lain-lain.

\section{DAFTAR PUSTAKA}

A.M, Sardiman. 2012. Interaksi dan Motivasi Belajar Mengajar, Jakarta: Raja Grafindo Persada.

Avi Hofstein Department of Science Teaching, The Weizmann Institute of Science,Rehovot 76100, Israel Vincent N. Lunetta Science Education, The Pennsylvania State University, University Park, PA 16802, USA. The Laboratory in Science Education: Foundations for the Twenty-First Century Received 23 June 2002; revised 10 January 2003; accepted 25 January 2003.

Badan Standar Nasional Pendidikan. 2007. Pedoman penyusunan Kurikulum Tingkat Satuan pendidikan di Sekolah Dasar.Jakarta: Departemen Pendididkan nasional

Depdiknas. 2006. Kurikulum Tingkat Satuan Pendidikan Sd. Jakarta: Depdiknas

Depdiknas, 2012. Undang-Undang Republik Indonesia. Jogjakarta: Laksana

Fogarty, Robin.1991 How to Integrate The Curricula. Unitet States of America: Skylight Publishing, Inc.

Hamalik. Oemar 2003. Proses Belajar Mengajar. Jakarta : Bumi Aksara.

Hamalik, Oemar. 2011. Kurikulum dan Pembelajaran. Jakarta: Bumi Aksara

Hake, R.R. 1999. American Educational Research Association, Division, Measurement and Research Methodology;Analyzing Change/Gain Scores.USA : Woodland Hills.

Han-Yu Sung a, Gwo-Jen Hwang. A collaborative gamebased learning approach to improving students' learning performance in science courses. November 2012. National Taiwan University of Science and Technology, 43, Sec. 4, Keelung Rd., Taipei 106, Taiwan
Huang, C. S. J., Yang, S. J. H., Chiang, T. H. C., \& Su, A. Y. S. (2016). Effects of Situated Mobile Learning Approach on Learning Motivation and Performance of EFL Students. Educational Technology \& Society, 19 (1), 263-276 (http://rizkapratiwijaya.blogspot.co.id/2013/04/pe mbelajaran-terpadu-model-networked.html). Disadur Desember 2015 .

Ibrahim, Muslimin dkk. 2008. Pembelajaran Kooperatif. Surabaya: Unesa-University Press.

Martin, Andy. Rees, Malcolm. Edwards, Manvir. Work Integrated Learning A Template for Good Practice: Supervisors' Reflections. Research undertaken at Massey University Published by Ako Aotearoa. October 2011

Nur, Mohammad. 2004. Teori Pembelajaran Kognitif. Surabaya: PSMS Unesa

Nur, Mohammad dan Prima Retno Wikandari. 2008. Pengajaran Berpusat Kepada Siswa dan Pendekatan Konstruktivis dalam Pengajaran. Surabaya: Unesa-University Press. Peraturan Menteri Pendidikan Naional 67 tahun 2013

Ratumanan, TG dan Teheresia Laurens. 2011. Penilaian Hasil Belajar Pada Tingkat Satuan Pendidikan Edisi 2. Surabaya : Unesa University Press.

Pritchard A. dan J. Woollard, 2010. Psychology for The Classroom: Contructivism and Social Learning. Oxon: Routledge.

Reys, Robert. 2009. Helping Children Learn Mathematic. The United States of America : John Wiley \& Sons, Inc.

Robert E. Yager. The University of Iowa, USA. ScienceTechnology-Society (STS) is recognized as reform in science education across the world.

Robert E.Yager The Status of Science - Technology Society Reform Efforts around the World. International Council of Assoclations for Science Education. ICASE YEARBOOK.1992

Sadik, Alaa. Digital storytelling: a meaningful technologyintegrated approach for engaged student learning. Published online: 11 April 2008. Association for Educational Communications and Technology 2008. Education Tech Research Dev (2008) 56:487-506 DOI 10.1007/s11423-008-9091-8

Sudjana, Nana. 2010. Proses Belajar Mengajar. Jakarta : Bumi Aksara.

Sudjana. Nana.1988.Pembinaan dan Pengembangan Kurikulum di Sekolah. Sinar Baru Algesindo : Bandung. 
Sung, H. Y., Hwang, G. J., \& Chang, H. S. (2015). An Integrated Contextual and Web-based Issue Quest Approach to Improving Students' Learning Achievements, Attitudes and Critical Thinking. Educational Technology \& Society, 18 (4), 299311.

Suprijono, Agus. 2005. Cooperative Learning. Yogyakarta: Pustaka Pelajar.

Trianto. 2007. Model-Model Pembelajaran Inovatif Berorientasi Konstruktivistik Konsep, Landasan Teoritis-Praktis dan Implementasiya. Jakarta: Prestasi Pustaka Publisher.

Trianto. 2010. Mendesain Pembelajaran Inovatif Progresif Konsep, Landasan \& Implementasinya pada KTSP. Jakarta : Kencana Prenada Media Group. 